\title{
Model Pembelajaran PAI di Lembaga Filantropi Pendidikan: Studi di Panti Asuhan Putra Al-Islam Yogyakarta
}

\author{
Naufal Ahmad Rijalul Alam*, Sadam Fajar Shodi, Ratna Sari \\ Universitas Muhammadiyah Yogyakarta \\ Email : *naufal.ahmad@umy.ac.id
}

\begin{abstract}
Abstrak. Artikel ini bertujuan untuk: 1) Merumuskan model pembelajaran PAI yang efektif di Lembaga filantropi Pendidikan, 2) Menganalisis faktor pendukung dan penghambat model pembelajaran PAI pada lembaga filantropi pendidikan di Yogyakarta. Penelitian ini merupakan penelitian kualitatif deskriptif. Model penelitian kualitatif ini menggunakan teknik analisis data Miles and Huberman. Pengambilan data dilakukan dengan teknik observasi dan wawancara. Kesimpulan yang dihasilkan adalah: 1) model pembelajaran PAI di Panti Asuhan Putra Al-Islam Giwangan menggunakan Model George Betts, 2) Faktor pendukung model pembelajaran PAI ada 5: (a) Sistem pembelajaran; (b) Lingkungan, sarana dan prasarana; (c) Strategi Pembelajaran; (d) Metode pembelajaran, dan (e) Media pembelajaran. Sedangkan faktor penghambat ada 3: (a) Ketidaksiapan pendidik dan peserta didik (b) Kurikulum yang tidak dijalankan secara penuh; (c) Terbatasnya jumlah buku pelajaran.
\end{abstract}

Keyword: Model Pembelajaran, PAI, Lembaga Filantropi.

\section{PENDAHULUAN}

Pendidikan adalah salah satu jalan yang bisa dilakukan untuk mencerdaskan kehidupan bangsa dan meningkatkan kualitas manusia Indonesia. Setiap manusia Indonesia berhak mendapatkan pendidikan yang berkualitas, baik itu dari segi layanan pendidikan, fasilitas maupun dari model pendidikannya. Pendidikan pada hakikatnya tidak hanya dilaksanakan di bangku sekolahan, akan tetapi pendidikan bisa dilaksanakan di manapun dan kapanpun. Pendidikan yang diakui oleh pemerintah Indonesia tidak hanya pendidikan formal saja, akan tetapi juga terdiri dari pendidikan nonformal dan informal.

Pendidikan merupakan ujung tombak kemajuan suatu bangsa. Bangsa yang bermartabat adalah bangsa yang memperhatikan pendidikan moral dan agama generasi mudanya. Pendidikan agama merupakan usaha untuk memperkuat iman dan ketakwaan terhadap Tuhan Yang Mahaesa sesuai dengan agama yang dianut oleh individu sebagai peserta didik dengan memperhatikan tuntutan untuk menghormati agama lain dalam hubungan kerukunan antar umat beragama dalam masyarakat untuk mewujudkan persatuan nasional . Lebih lanjut Muhaimin memaparkan bahwa pendidikan agama Islam adalah usaha sadar untuk menyiapkan peserta didik dalam meyakini, memahami, menghayati, dan mengamalkan agama Islam melalui kegiatan bimbingan, pengajaran, dan atau latihan dengan memperhatikan tuntutan untuk menghormati agama lain agar persatuan nasional dapat terwujud .

Usaha untuk menyiapkan individu untuk tidak hanya meyakini, namun juga memahami, menghayati, dan mengamalkan ajaran agama tentu bukan hal yang mudah. Pendidikan formal sejak 
pra Sekolah Dasar hingga Sekolah Menengah Atas telah mengajarkan mata pelajaran Pendidikan Agama Islam (PAI) melalui proses pendidikan formal. Namun proses pembelajaran PAI pada pendidikan formal ini terbatas di dalam ruang kelas dengan waktu yang sangat terbatas, sehingga masih banyak ditemukan peserta didik yang belum mampu memahami bahkan mengamalkan keyakinan yang dianutnya. Ketidakmampuan peserta didik dalam memahami dan mengamalkan agama akan berakibat pada tingkah laku peserta didik di luar koridor aturan agama, degradasi moral yang berujung pada kenakalan remaja.

Lembaga filantropi pendidikan merupakan lembaga filantropi yang memusatkan bidang kerjanya pada bidang pendidikan. Lembaga ini merupakan penyedia pendidikan alternatif bagi masyarakat. Sudah semestinya lembaga filantropi pendidikan menyelenggarakan pembelajaran PAI sebagai jawaban terbatasnya pemberian mata pelajaran PAI di sekolah formal. Selain itu sebagai langkah preventif menanggulangi kenakalan anak usia sekolah, khususnya remaja.

Tahap perkembangan remaja merupakan fase yang sangat penting bagi individu sebagai dasar tahap perkembangan selanjutnya, yaitu tahap dewasa. Pada masa ini remaja mengalami beberapa perubahan, tidak hanya perubahan fisik namun juga psikis, sehingga dukungan lingkungan khususnya orang tua dan lingkungan belajar menjadi sangat penting pada fase perkembangan ini. Teori ekologi yang dikembangkan Bronfenbrenner dalam Santrock, yang menyebutkan bahwa tempat di mana individu tinggal dan orang-orang di sekelilingnya mempengaruhi perkembangannya.

Model pembelajaran agama khususnya Pendidikan Agama Islam (PAI) seharusnya memperhatikan tahap perkembangan remaja. Model pembelajaran yang tepat tidak hanya dapat menyampaikan materi dengan baik namun juga menggugah keinginan remaja untuk mau mengamalkan apa yang sudah dipelajarainya. Mestinya model pembelajaran ini juga harus mampu menjawab kegelisahan remaja atau permasalahan-permasalahan remaja yang tidak dapat diselesaikan secara individu, serta membantunya dalam menentukan konsep dirinya. Agama seharusnya dapat menjadi guidance atau tuntunan bagi remaja dalam menentukan jati dirinya. Dengan demikian, kebutuhan akan pengembangan model pembelajaran PAI di lembaga filantropi pendidikan sangat mendesak untuk dilakukan, karena hal ini merupakan salah satu wujud kepedulian dalam memperbaiki akhlak generasi muda penerus bangsa.

\section{METODE}

Jenis penelitian ini adalah penelitian kualitatif yang memiliki beberapa karakteristik yaitu berlangsung dalam latar belakang ilmiah, peneliti adalah instrumen atau alat pengumpul data yang utama, dan analisisnya dilakukan secara induktif. (Moleong, 2006) Penelitian lapangan dan bersifat deskriptif kualitatif yang bertujuan untuk mengungkapkan suatu masalah atau keadaan, peristiwa sebagaimana adanya berdasarkan data-data tertulis yang dipandang relevan dan mendukung berkaitan dengan model pembelajaran PAI pada lembaga filantropi di Yogyakarta.

Penelitian ini menggunakan pendekatan studi kasus konseptual, yaitu suatu penelitian yang diarahkan untuk menghimpun data, mengambil makna, memperoleh pemahaman dari kasus tersebut. (Sugiyono, 2005) Pendekatan dilakukan dengan mengamati dan memahami keadaan riil yang ada pada 
model pembelajaran PAI pada lembaga filantropi di Yogyakarta.

\section{Model Pembelajaran}

Keberhasilan proses pembelajaran tidak terlepas dari kemampuan guru dalam mengembangakan model-model pembelajaran yang berorientasi pada peningkatan intensitas keterlibatan peserta didik secara aktif dalam proses pembelajaran. Pengembangan model pembelajaran yang tepat pada dasarnya untuk menciptakan kondisi pembelajaran yang memungkinkan siswa dapat meraih hasil belajar dan prestasi secara maksimal. Pengembangan model pembelajaran tidak terlepas dari pengetahuan mengenai konsep dan kemampuan guru dalam mengimplementasikan model pembelajaran tersebut. Dalam pengembanagan pembelajaran harus memperhatikan faktor-faktor yang terkait dalam proses pembelajaran seperti kondisi siswa, fasilitas, lingkungan pembelajaran yang ada, dan faktor lain yang mempengaruhi pembelajaran. Tanpa memperhatikan faktor-faktor tersebut, pengembangan model pembelajaran yang dilakuakan tidak akan mampu meningkatkan kemampuan peserta didik. Model pembelajaran jumlahnya sangat banyak sekali akan tetapi hanya beberapa model pembelajaran yang akan dibahas di sini yang kemudian model pembelajaran tersebut nantinya akan diadikan acuan dalam merumuskan pengembangan model pembelajaran PAI di lembaga filantropi pendidikan. Model pembelajaran tersebut antara lain:

a. Model George Betts

Model pembelajaran yang dikembangkan oleh Goerge Betts ini didasarkan pada konsep "pembelajar mandiri" (autonomous learner). Pembelajar mandiri adalah mereka yang mampu menyelesaikan masalah atau mengembangkan gagasan-gagasan baru dengan mengkombinasikan cara berpikir divergen dan konvergen tanpa terlalu banyak dibantu orang luar untuk emmilih bidang-bidang tindakan yang dikehendakinya. (Huda, 2014, hal. 144-45). Tujuan model pembelajaran ini adalah memfasilitasi perkembangan peserta didik agar menjadi pembelajar yang independen, mandiri, dengan pengembangan skill konsep-konsep, dan sikap-sikap positif dalam ranah kognitif, emosional, dan sosial. Model pembelajaran ini dapat digunakan secara fleksibel dalam berbagai situasi dan kondisi. Fokus utama model pembelajaran ini adalah belajar seumur hidup.

Lima dimensi dalam model pembelajaran Goerge Betts, yaitu:

1) Orientasi, yaitu dengan memahami bakat dan potensi, aktivitas-aktivitas kelompok, pengembangan diripersonal

2) Pengembangan individual dengan pemahaman intra atau inter personal, skill-skill belajar, dan pemanfaatan teknologi.

3) Kekayaan yaitu tentang pelajaran, eksplorasi, investigasi, aktivitasaktivitas kultural, layanan masyarakat, dan darmawisata.

4) Seminar yaitu dengan presentasi kelompok kecil

5) Studi mendalam melalui proyek-proyek individu, kelompok, presentasi penilaian diri dan orang lain.

b. Model Osborn-Parne

Model ini menginisiasi model pembelajaran yang disebut model Proses Pemecahan Masalah Kreatif (creative problem solving process). Model ini merupakan perangkat fleksibel yang dapat diimplementasikan untuk menguji problem dan isu-isu nyata. Ada enam tahapan dalam model ini yang mempresentasikan prosedur sistematis dan mengidentifikasi tantangan, menciptakan 
gagasan, dan menerapkan solusi-solusi inovatif. Melalui praktik dan penerapan proses secara kontinu, peserta didik dapat memperkuat teknik pemecahan masalah mereka secara kreatif.

Model pembelajaran ini dapat diterapkan melalui enam tahapan, yaitu:

1) Penemuan Tujuan yakni mengidentifikasi tujuan, tantangan dan arah masa depan.

2) Penemuan Fakta yakni mengumpulkan data tentang masalah, kemudian melakukan observasi secara objektif.

3) Pemecahan Masalah yakni menguji berbagai masalah, kemudian ditentukan mana masalah yang harus membutuhkan penanganan secara prioritas.

4) Penemuan Gagasan yakni menciptakan sebanyak mungkin gagasan terkait maslah yang dihadapi.

5) Penemuan Solusi yakni memilih solusi yang terbaik dari gagasan-gagasan yang telah diciptakan.

6) Penerimaan yakni membuat rencana tindakan. (Huda, 2014, hal. 148)

c. Model Gardner

Model pembelajaran yang dikembangakan oelh Howard Gardner ini sering disebut dengan Multiple intelligences (kecerdasan berganda atau majemuk). Kajian Gardner tentang kecerdasan ganda telah memberi model pedagogik bagi para pendidik untuk menjawab sebuah pertanyaan tentang bagaimana seseorang bisa cerdas. Model pembelajaran ini menegaskan bahwasannya semua orang memiliki potensi masing-masing yang dapat dikembangkan. Pada model pembelajaran ini seorang pendidik tidak boleh menghukumi seorang peserta didik sebagai siswa yang bodoh atau pintar dalam hal tertentu, karena pada dasarnya kemampuan dasar yang dimiliki oleh masing-masing individu berbeda-beda.

Kecerdasan ganda yang dikembangkan oleh Gardner ada delapan aspek, yaitu kecerdasan matematis-logis, kecerdasan spasial, kecerdasan linguistik, kecerdasan kinestetik-jasmani, kecerdasan musikal, kecerdasan interpersonal, kecerdasan intrapersonal, dan kecerdasan naturalistik. Selain delapan kecerdasan tersebut,para pendukung Gardner memasukkan kecerdasan eksistensial, kecerdasan ini berkaitan dengan spiritual dan religius. (Huda, 2014, hal. 155-157)

d. Model Bloom

Domain kognitif adalah domain pembelajaran inti di sekolah dan setidaknya sejumlah komponen kognitif hadir dalam domain pembelajaran yang lain. (Eggen \& Kauchak, 2012, p. 9) Ranah kognitif melibatkan pengetahuan dan pengembangan skill-skill intelektual. Model Taksonomi Bloom Ranah Kognitif mencakup ingatan dan pengenalan terhadap fakta-fakta tertentu, pola-pola procedural dan konsep-konsep yang memungkinkan berkembangnya kemampuan dan skill intelektual (Huda, 2014, hal. 169).

\section{HASIL DAN PEMBAHASAN}

Pembelajaran PAI di Panti Asuhan Putra al-Islam Giwangan terbagi dalam beberapa bidang studi yaitu aqidah, fiqh, akhlak, tarikh atau sejarah, dan al-Qur'an. Tujuan yang telah ditetapkan oleh panti asuhan putra al-Islam Giwangan adalah mengenalkan agama ke peserta didik dari segi pengetahuan akidah, akhlak, sejarah Islam, dan praktik Ibadah yang sederhana. Pembelajaran PAI di Panti Asuhan Putra alIslam Giwangan juga menanamkan nilainilai karakter, seperti kemandirian, kerjasama, dan lain sebagainya. Meskipun nilai-nilai karakter tersebut tidak tertuliskan dalam dokumen pembelajaran yang ada. Tujuan pembelajaran tersebut ditentukan berdasarkan analisis kebutuhan yang ada, dimana panti tersebut mengharapkan agar setiap peserta 
didiknya memiliki terbiasa hidup mandiri dan tidak berpangku kepada orang lain dalam menjalani hidupnya. Hal itu dilakukan karena dari pihak panti melihat latar belakang peserta didiknya yang mayoritas jauh dari orang tua, dan orang tua mereka dari golongan ekonomi lemah atau kurang mampu.

Tujuan pembelajaran dalam bidang studi aqidah yang diajarkan di Panti Asuhan Putra al-Islam Giwangan adalah memberikan dasar aqidah yang kuat pada diri peserta didik sehingga dalam menjalankan perintah Allah dapat konsisten, tidak mudah terpengaruh oleh arus globalisasi. Dalam bidang studi akhlak tujuan pembelajarannya adalah mengajarkan bagaimana berakhlak kepada sesama manusia agar tidak membedabedakan antara satu dengan yang lainnya. Tujuan tersebut senada dengan yang disampaikan dalam peraturan menteri agama no 912 tahun 2013 yang menyebutkan bahwa tujuan bidang studi akidah-akhlak mengarahkan pada pencapaian kemampuan dasar peserta didik dalam untuk dapat memahami dasardasar akidah (rukun iman) secara sederhana serta pengamalan dan pembiasaan berakhlak Islami secara sederhana pula, untuk dapat dijadikan perilaku dalam kehidupan sehari-hari serta sebagai bekal dalam untuk jenjang berikutnya. Secara substansial bidang akidah-akhlak memiliki kontribusi dalam memberikan motivasi kepada peserta didik untuk mempelajari dan mempraktikkan akidahnya dalam bentuk pembiasaan dalam rangka mengantisipasi dampak negatif dari era globalisasi dan krisis multidimensional yang melanda bangsa dan Negara Indonesia.

Bidang studi sejarah Islam di Panti Asuhan Putra al-Islam Giwangan bertujuan untuk mengenalkan kepada diri peserta didik akan pengorbanan ulama' terdahulu dalam berdakwah, sehinga peserta didik bisa meniru semangat ulama' terdahulu dalam berdakwah dan beragama. Tujuan bidang studi sejarah Islam di Panti Asuhan Putra al-Islam Giwangan di atas sesuai dengan apa yang telah ditetapkan pemerintah yang termaktub dalam peraturan menteri agama no 912 tahun 2013 bahwasannya mata pelajaran sejarah Islam bertujuan agar peserta didik memiliki kemampuan-kemampuan sebagai berikut: (1) membangun kesadaran peserta didik tentang pentingnya mempelajari landasan ajaran, nilai-nilai dan norma-norma Islam yang telah dibangun oleh rasulullah dalam rangka mengembangkan kebudayaan dan peradaban Islam. (2) membangun kesadaran peserta didik tentang pentingnya waktu dan tempat yang merupakan sebuah proses dari masa lampau, masa kini, dan masa depan. (3) melatih daya kritis peserta didik untuk memahami fakta sejarah secara benar dengan didasarkan pada pendekatan ilmiah. (4) menumbuhkan apresiasi dan penghargaan peserta didik terhadap peninggalan sejarah Islam sebagai bukti peradaban umat Islam di masa lampau. (5) mengembangkan kemampuan peserta didik dalam mengambil ibrah dari peristiwa-peristiwa bersejarah, meneladani tokoh-tokoh berprestasi, dan mengaitkannya dengan fenomena sosial, budaya, politik, ekonomi, iptek, dan seni untuk mengembangkan kebudayaan dan peradaban Islam.

Tujuan bidang studi ibadah bertujuan untuk mengajarkan kepada peserta didik agar ibadah yang meraka laksanakan sesuai dengan tuntunan yang terdapat dalam al-Qur'an dan sunah. Tujuan tersebut selaras dengan peraturan menteri agama no 912 tahun 2013 bahwa bidang studi ibadah bertujuan untuk membekali 
peserta diidk agar dapat memahami pokok-pokok hukum Islam yang mengatur tentang tata cara menjalankan hubungan manusia dengan Allah yang diatur dalam fikih ibadah dan hubungan manusia dengan sesama yang diatur dalam fikih muamalah. Pengamalan tersebut diharapkan menumbuhkan ketaatan menjalankan hukum Islam, disiplin dan tangungjawab sosial yang tinggi dalam kehidupan pribadi maupun sosial.

Secara keseluruhan tujuan pembelajaran pendidikan agama Islam di Panti Asuhan Putra al-Islam Giwangan tersebut di atas sesuai dengan apa yang telah ditetapkan pemerintah yang tertuang dalam undang-undang no 20 tahun 2003 bahwa pendidikan berfungsi mengembangkan kemampuan dan membentuk watak serta peradaban bangsa yang bermartabat dalam rangka mencerdaskan kehidupan bangsa, bertujuan untuk berkembangnya potensi peserta didik agar menjadi manusia yang beriman dan bertakwa kepada Tuhan yang Maha Esa, berakhlak mulia, sehat, berilmu, cakap, mandiri, dan menjadi warga yang demokratis serta bertanggung jawab dalam segala urussan yang enjadi tanggung jawabnya.

Karakteristik pembelajaran PAI yang diajarkan di Panti Asuhan Putra al-Islam Giwangan itu dapat dijelaskan sebagai berikut :

1. Pembelajaran PAI di Panti Asuhan Putra Al-Islam Giwangan mencakup dari berbagai bidang kajian pokok dalam Islam, yaitu Aqidah, Akhlak, al-Qur'an, Fiqh, dan Tarikh atau sejarah, dimana dalam berbagai bidang studi tersebut memiliki tujuan akhir menjadikan peserta didik sebagai insan kamil.

2. Tujuan PAI di Panti Asuhan Putra AlIslam Giwangan adalah terbentuknya peserta didik yang beriman dan bertaqwa kepada Allah SWT, berbudi pekerti yang luhur (berakhlak mulia), memiliki pengetahuan tentang ajaran pokok Agama Islam dan mengamalkannya dalam kehidupan sehari-hari, serta memiliki pengetahuan yang luas dan mendalam tentang Islam, sehingga memadai baik untuk kehidupan masyarakat maupun untuk melanjutkan pendidikan ke jenjang yang lebih tinggi.

3. Pembelajaran PAI di Panti Asuhan Putra Al-Islam Giwangan lebih menekankan pada aspek afektif dan psikomotorik, akan tetapi tidak mengabaikan kognitif.

4. Isi materi pembelajaran PAI di Panti Asuhan Putra Al-Islam Giwangan didasarkan dan dikembangkan dari buku ajar yang dikeluarkan oleh Kemenag.

5. Tujuan akhir pembelajaran PAI di Panti Asuhan Putra Al-Islam Giwangan adalah terbentuknya peserta didik yang memiliki akhlakl karimah (budi pekerti luhur) yang merupakan jiwa pendidikan dalam Islam, sebagaimana misi rasulullah diutus dimuka bumi ini sehingga pencapaian akhlakul karimah (mulia) adalah tujuan sebenarnya dalam pendidikan.

Penerapan model pembelajaran di suatu institusi pendidikan tidak dapat dilakukan tanpa adanya faktor-faktor pendukung dan penghambat. Berikut ini merupakan faktor-faktor pendukung dan penghambat model pembelajaran di PAY Putra al-Islam;

1. Faktor Pendukung Model Pembelajaran a. Sistem Pembelajaran

Kegiatan pembelajaran yang sistematis dapat mempermudah pendidik dalam melakukan tugasnya selama proses pembelajaran sehingga dapat dicapai kualitas hasil pembelajaran atau tujuan pembelajaran yang sudah ditetapkan. Dalam penerapan sebuah pendekatan sistem 
pembelajaran terdapat beberapa proses kegiatan yang harus dilakukan, yaitu; mengidentifikasi kebutuhan, memilih problem, mengidentifikasi syarat-syarat pemecahan problem, memilih alternatif pemecahan problem yang tepat, mengevaluasi hasil dan merevisi sebagian atau seluruh sistem yang dilaksanakan sehingga dapat memenuhi kebutuhan dalam memecahkan masalah dengan sebaik-baiknya (Muhaimin, 2012).

PAY Putra al-Islam telah menerapkan pendekatan sistem pembelajaran dalam proses pembelajaran. Telah dilakukan identifikasi kebutuhan terutama mengidentifikasi kebutuhan masyarakat. Dari berbagai macam masalah pendidikan yang ada di lingkungan masyarakat, PAY Putra alIslam menetapkan bahwa masalah yang paling mendesak untuk diatasi adalah pentingnya bekal pendidikan agama bagi anak dalam era degradasi moral saat ini. Selanjutnya PAY Putra al-Islam merencanakan program pembelajaran PAI di luar sekolah, menyusun kurikulum secara mandiri, serta mempersiapkan materi ajar untuk dijadikan sebagai syarat pemecahan masalah.

Selanjutnya diambil alternatif solusi bagi masalah yang dihadapi, yaitu; pembentukan lembaga pendidikan yang bergerak dalam pembelajaran Pendidikan Agama Islam. Dalam lembaga yang saat ini disebut sebagai PAY Putra al-Islam ini berusaha untuk menyampaikan materi pembelajaran PAI secara lebih detail dan lengkap dibandingkan sekolah umum, serta mengutamakan adanya pembiasaan bagi peserta didik dalam menjalankan ajaran agama dalam kehidupan seharihari.
Namun demikian, belum terdapat evaluasi maupun revisi terhadap sistem pembelajaran di PAY Putra al-Islam. Evaluasi ini sangat penting untuk dilakukan demi tercapainya tujuan pembelajaran dan terlaksananya model pembelajaran sesuai dengan perencanaan.

\section{b. Lingkungan Belajar dan Sarana dan} Prasarana

Lingkungan belajar dan Sarana dan prasarana merupakan unsur pendukung dalam kegiatan pembelajaran yang tidak bisa dikesampingkan. Keduanya merupakan faktor non sosial yang mempengaruhi proses belajar peserta didik. Lingkungan belajar merupakan lokasi berlangsungnya kegiatan belajar mengajar. Penerapan sebuah model pembelajaran penting untuk mempertimbangkan lingkungan belajar di mana proses pembelajaran berlangsung.

Lingkungan belajar di PAY Putra alIslam terpusat dalam satu komplek dengan pembagian ruang-ruang kelas yang sudah tetap dan jelas sehingga menciptakan iklim belajar yang kondusif. Lingkungan belajar yang kondusif ini berpengaruh terhadap minat dan motivasi belajar peserta didik. Peserta didik merasa nyaman berada di lingkungan belajar PAY Putra al-Islam sehingga mengikuti proses pembelajaran dengan baik. Hal ini akan berujung pada tercapainya tujuan pembelajaran yang telah dirancang sebelumnya.

Sebuah proses belajar mengajar dapat berjalan dengan baik dan lancar apabila didukung dengan ketersediaan sarana dan prasarana yang memadai. Sarana dan prasarana di PAY Putra alIslam berupa; 
1) Gedung, yaitu: ruang belajar, ruang ibadah / masjid, tempat istirahat di ruang terbuka.

2) Alat-alat belajar, seperti: meja, kursi, papan tulis, proyektor, buku-buku, Iqra, Al Qur' an dan alat peraga.

Dengan melihat sarana dan prasarana yang dipersiapkan PAY Putra al-Islam di atas, dapat disimpulkan bahwa sarana dan prasarana sudah cukup lengkap untuk mendukung sistem pembelajaran peserta didik.

c. Strategi pembelajaran

Strategi pembelajaran merupakan semua komponen materi atau paket pengajaran dan prosedur yang digunakan untuk membantu siswa dalam mencapai tujuan pembelajaran (Yamin, 2010). Komponen materi yang diajarkan di PAY Putra al-Islam telah dirancang berdasarkan kebutuhan dan kemampuan peserta didik dengan mempertimbangkan asal peserta didik. Sebagaimana hasil observasi diketahui bahwa peserta didik di PAY Putra alIslam tidak semua berasal atau tinggal menetap di PAY Putra al-Islam, namun ada juga peserta didik yang berasal dari luar panti asuhan dan datang ke PAY Putra al-Islam dengan tujuan belajar agama. Berikut ini tabel komponen materi di PAY Putra al-Islam.

$\begin{array}{ccr}\text { Lebih } & \text { jauh Yamin } & \text { (2010) } \\ \text { memaparkan } & \text { bahwa } & \text { strategi } \\ \text { pembelajaran } & \text { merupakan } & \text { suatu }\end{array}$ perencanaan yang dibuat pendidik dalam mengefektifkan, mengefisienkan, dan mengoptimalkan fungsi serta interaksi antara peserta didik dengan komponen pembelajaran dalam suatu proses kegiatan belajar mengajar, dalam rangka tercapainya tujuan pembelajaran. Perencanaan mengenai komponen pembelajaran telah dilakukan oleh PAY Putra al-Islam dengan mengacu pada Kurikulum Kementerian Agama. Selain itu perencanaan yang berpusat pada pembelajaran peserta didik juga telah diaplikasikan dengan adanya proses screening terhadap kemampuan peserta didik sehingga dapat berada di kelas yang tepat sesuai dengan kemampuan dan kebutuhannya.

\section{d. Metode Pembelajaran}

Metode pembelajaran merupakan cara yang digunakan untuk mengaplikasikan rencana pembelajaran yang sebelumnya telah disusun. Metode ini diterapkan dalam kegiatan atau proses belajar mengajar guna tercapainya tujuan pembelajaran. Terdapat beberapa macam metode pembelajaran, antara lain; ceramah, diskusi, demonstrasi, simulasi, dan lainlain.

Sebagian besar pendidik di PAY Putra al-Islam telah menerapkan metode pembelajaran sesuai dengan materi yang diajarkan. Berikut ini merupakan tabel metode pembelajaran yang diterapkan di PAY Putra al-Islam;

1) Ceramah

Metode ceramah merupakan metode pembelajaran yang masih digunakan oleh para pendidik di PAY Putra alIslam. Hal ini terjadi karena beberapa pendidik masih menemukan kesulitan untuk menentukan metode pembelajaran lain yang dapat digunakan dalam proses pembelajaran yang sesuai dengan materi yang disampaikan.

2) Diskusi

Metode diskusi telah diaplikasikan khususnya dalam pembelajaran materi Akhlak di kelas besar. Dalam proses pembelajarannya pendidik meminta peserta didik untuk mendiskusikan teori yang telah dipelajari dengan dikaitkan dengan 
fakta-fakta yang terjadi di masyarakat.

3) Demonstrasi

Metode pembelajaran demonstrasi digunakan dalam penyampaian materi Iqra dan Al Qur'an serta sholat. Dalam proses pembelajarannya guru akan mendemonstrasikan langkahlangkah yang benar untuk selanjutnya dicontoh oleh peserta didik.

e. Penggunaan Media Pembelajaran Media pembelajaran yang digunakan dalam proses belajar mengajar di PAY Putra Al-Islam antara lain media papan tulis dan proyektor. Papan tulis digunakan untuk menjelaskan materi pembelajaran, sementara proyektor untuk menampilkan slide power point materi dan menampilkan film yang diputar melalui laptop. Film yang diputar merupakan film yang memiliki keterkaitan dengan materi pembelajaran. Selain itu juga diputar film-film motivasi untuk membangkitkan semangat belajar peserta didik.

2. Faktor Penghambat Model

Pembelajaran

a. Kesiapan pendidik dan peserta didik Pendidik adalah unsur utama dalam proses pembelajaran. Guru ibarat nahkoda yang akan mengarahkan proses pembelajaran menuju tujuan pembelajaran yang sudah ditetapkan sebelumnya. Penerapan model pembelajaran harus didukung pula oleh kesiapan pendidik dalam mengkondisikan peserta didik untuk mengikuti proses pembelajaran. Dari hasil observasi didapatkan fakta bahwa para pendidik di PAY Putra al-Islam masih menjalankan kelasnya masing-masing tanpa mengacu pada suatu model pembelajaran.

b. Sistem Pembelajaran

Dalam sistem pembelajaran terdapat komponen yang sangat penting yaitu Kurikulum. PAY Putra al-Islam tidak menggunakan kurikulum yang telah disusun oleh Kementerian Agama (Kemenag), dengan alasan konten materi dalam kurikulum tersebut tidak sesuai dengan kemampuan peserta didik di panti asuhan. Sementara itu, bagian Kurikulum PAY Putra al-Islam telah menyusun kurikulum dengan disesuaikan pada kebutuhan peserta didik PAY Putra al-Islam, namun beberapa pendidik merasa bahwa kurikulum tersebut masih belum lengkap sehingga pendidik tidak mempunyai panduan yang baku dalam melaksanakan proses pembelajaran.

c. Lingkungan Belajar dan Sarana dan Prasarana

Prasarana berupa buku mata pelajaran telah dimiliki oleh PAY Putra al-Islam, namun selama ini hanya digunakan sebagai pegangan guru. Hal ini terjadi dikarenakan oleh terbatasnya jumlah buku pelajaran yang dimiliki, sehingga membatasi peserta didik dalam mengeksplorasi materi yang diajarkan karena peserta didik hanya bersifat sebagai penerima ilmu yang disampaikan oleh pendidik.

\section{KESIMPULAN}

Berdasarkan permasalahan yang telah dirumuskan dan berdasarkan hasil penelitian dengan teknik pengumpulan data wawancara, observasi, dan dokumentasi dan hasil analisis data melalui teknik analisis data yang dikembangkan oleh Miles \& Huberman tentang model pembelajaran PAI pada lembaga filantropi di Yogyakarta 
khususnya di Panti asuhan Putra al-Islam Giwangan ditinjau dari tujuan pembelajaran, karakteristik mata pelajaran, karakteristik peserta didik, sumber belajar, tujuan dan Karakteristik Bidang Studi, Sumber Belajar, karakteristik Peserta Didik, tujuan Belajar dan Isi Pembelajaran, strategi Pengorganisasian Isi Pembelajaran, strategi Penyampaian Isi Pembelajaran, strategi Pengelolaan Pembelajaran, prosedur Pengukuran Hasil Pembelajaran bawasannya model pembalajaran PAI pada lembaga filantropi di Yogyakarta khususnya di Panti Asuhan Putra Al-Islam Giwangan adalah Model George Betts, akan tetapi tidak sepenuhnya terpaku pada model tersebut. Model pembelajaran pada lembaga filantropi di Yogyakarta khususnya di Panti Asuhan Putra Al-Islam Giwangan juga tidak mengenyampingkan model pembelajaran lainnya, karena pada dasarnya tidak menuliskan secara eksplisit dalam dokumennya untuk menerapkan salah satu model pembelajaran.

Faktor pendukung model pembelajaran PAI pada lembaga Filantropi di Yogyakarta khususnya di Panti Asuhan Yatim Putra Giwangan dipengaruhi oleh faktor-faktor berikut (1) Sistem pembelajaran yang sudah berjalan dengan baik; (2) Lingkungan, sarana dan prasarana yang mendukung; (3) Strategi Pembelajaran menyesuaikan dengan kondisi siswa; (4) Metode pembelajaran menggunakan ceramah, diskusi, dan demonstrasi dan (5) Media pembelajaran terpenuhi. Sedangkan faktor penghambatnya adalah: (1) Ketidaksiapan pendidik dan peserta didik. Para Pendidik masih menjalankan kelasnya masingmasing tanpa mengacu pada suatu model pembelajaran. (2) Kurikulum yang dipakai mengacu kepada Kementerian Agama (Kemenag), tapi tidak dijalankan secara penuh, karena konten materi dalam kurikulum tidak sesuai dengan kemampuan peserta didik; (3) Terbatasnya sarana dan prasarana belajar, terutama jumlah buku pelajaran.

\section{DAFTAR PUSTAKA}

Aunurrahman. (2012). Belajar dan Pembelajaran. Bandung: Alfabeta.

Desmita. (2015). Psikologi Perkembangan. Bandung: Remaja Rosdakarya.

Eggen, P., \& Kauchak, D. (2012). Strategi dan Model Pembelajaran: Mengajarkan Konten dan Keterampilan Berpikir. Jakarta: Indeks.

Gall, M. D., Gall, J. P., \& Borg, W. R. (2003). Educational Research. Boston: Longman.

Huda, M. (2014). Model-model Pengajaran dan Pembelajaran: Isu-isu Metodis dan Paradigmatis. Yogyakarta: Pustaka Pelajar.

Joyce, B., Weil, M., \& Calhoun, E. (2009). Models Of Teaching: Model-model Pengajaran. Yogyakarta: Pustaka Pelajar.

Moleong, L. J. (2006). Metodologi Penelitian Kualitatif. Bandung: Remaja Rosdakarya.

Muhaimin, Suti'ah, \& Ali, N. (2012). Paradigma Pendidikan Islam: Upaya Mengefektifkan Pendidikan Agama Islam di Sekolah. Bandung: Remaja Rosdakarya.

Ngalimun. (2012). Strategi dan Model Pembelajaran. Yogyakarta: Aswaja Pressindo.

Purwanto, M. N. (2011). Psikologi Pendidikan. Bandung: Remaja Rosdakarya.

Santrock, J. W. (2011). Psikologi Pendidikan. Jakarta: Kencana.

Schunk, D. H. (2012). Learning Theories anEducation Perspective. Yogyakarta: Pustaka Pelajar.

Sobur, A. (2013). Psikologi Umum dalam Lintasan Sejarah. Bandung: Pustaka Setia. 


\section{Jurnal}

Sugiyono. (2005). Metode Penelitian

Kualitatif dan Kuantitatif. Bandung:

Alfabeta.

Sunhaji. (2009). Strategi Pembelajaran:

Konsep Dasar, Metode, dan

Aplikasi dalam Proses Belajar

Mengajar. Yogyakarya: Grafindo

Litera Media.

Syaodih, N. (2005). Metode Penelitian

Pendidikan. Bandung: Remaja

Rosdakarya. 